\title{
Deoxyribonucleic Acid Homologies Among Three Immunological Types of Corynebacterium renale (Migula) Ernst
}

\author{
EIICHI HONDA and RYO YANAGAWA \\ Department of Hygiene and Microbiology, Faculty of Veterinary Medicine, Hokkaido University, \\ Sapporo, Japan
}

\begin{abstract}
Deoxyribonucleic acid hybridization among three immunological types of Corynebacterium renale (Migula) Ernst was carried out. The data indicated that hybridizations between the different types were lower than those obtained in the homologous systems and that the three types of $C$. renale are not too closely related.
\end{abstract}

Corynebacterium renale (Migula) Ernst is a species which causes pyelonephritis and cystitis in cattle. Three types of $C$. renale were identified in our laboratory by the antigenicities of their cell wall extracts by immunodiffusion (25). Differences in some biochemical properties were also shown: xylose was fermented only by the strains of type III, and nitrate was reduced only by the strains of type II (25). Further differences between the three types were found: the strains of type III required more growth factors and amino acids than the strains of other types (13); the strains of type II had numerous pili, whereas those of type I and usually those of type III had a small number of pili $(26,27)$; lysogeny was found only in strains of type I (28). Virulence for cows was also different between the three types: the strains of type III caused severe hemorrhage, epithelial degeneration, and ulceration of the mucous membrane in the urinary bladder. The strains of type I caused cystitis less severe than those of type III, and the strains of type II were least in virulence (14). Differences in their deoxyribonucleic acid (DNA) base compositions were also confirmed (17). Averages of the guanine plus cytosine (GC) contents expressed in percentage were $56.7 \pm 1.1$ (type I strains including ATCC 10848), $57.9 \pm 1.9$ (type II strains including strains 45 and 46 ), and $53.5 \pm 0.9$ (type III strains including strains 42 and 43 ).

The present study was undertaken, using strains employed in previous studies, to determine what relationships exist, if any, among the three types of $C$. renale by the DNA hybridization technique.

\section{MATERIALS AND METHODS}

Bacterial strains. Strains of $C$. renale used in the present study were American Type Culture Collection (ATCC) 10848 and ATCC 19412 (type I), strains 45 and 46 (type II), and strains 42 and 43 (type III), all isolated from cows with signs of pyelonephritis. The typing of these organisms was done by immunodiffusion (25). Radiolabeled DNA was extracted from ATCC 10848 (type I), strains 46 (type II), and 42 (type III). Control strains were $C$. pseudotuberculosis (ATCC 809), which, on the basis of a numerical taxonomy study is not too closely related to $C$. renale (10), and Escherichia coli $\mathrm{O}-111$, which is known to be taxonomically remote from $C$. renale. Two strains of $E$. coli $\left(\mathrm{H} / \mathrm{r} 30 \mathrm{RT}^{+}\right.$and $\left.\mathrm{H} / \mathrm{r} 30 \mathrm{RT}^{-}\right)$were used only in the test of thymidine kinase activity.

Media and cultural techniques. Cells were grown in nutrient broth or in a Casamino Acids medium containing $0.5 \%$ Casamino Acids (Difco) and $0.5 \%$ $\mathrm{NaCl}$. Nutrient agar with $0.5 \%$ glucose was also used. The $\mathrm{pH}$ of the media was 7.2. The organisms were grown at $37 \mathrm{C}$ for $48 \mathrm{~h}$, except for $E$. coli, which was grown at $37 \mathrm{C}$ for $24 \mathrm{~h}$.

Enzymes and radioisotopes. Ribonuclease (RNase) (EC class 2.7.7.16) and deoxyribonuclease (DNase) (EC class 3.1.4.5) were purchased from Sigma Chemical Corp. (St. Louis, Mo.). ${ }^{3} \mathrm{H}$-thymidine $(5.0 \mathrm{Ci} /$ $\mathrm{mmol}, 20.5 \mathrm{mCi} / \mathrm{mg})$ and ${ }^{3} \mathrm{H}$-uridine $(5.0 \mathrm{Ci} / \mathrm{mmol}$, $20.6 \mathrm{mCi} / \mathrm{mg}$ ) were purchased from the Radiochemical Centre (Amersham, England).

Preparation of DNA. DNA was extracted and purified by a modified phenol extraction procedure previously described (17).

Preparation of labeled DNA. As described below, the DNA of the strains of $C$. renale was not labeled when cultivated in the presence of ${ }^{3} \mathrm{H}$-thymidine. Therefore, ${ }^{3} \mathrm{H}$-uridine was used for labeling the bacterial DNA. Incorporation of tritium from ${ }^{3} \mathrm{H}-$ uridine into DNA has been reported (1). Labeled DNA was extracted from the organisms, which were 
cultivated in the broth containing 1 to $1.5 \mu \mathrm{Ci}$ of ${ }^{3} \mathrm{H}$-uridine per $\mathrm{ml}$ and harvested immediately before the stationary phase and purified as described above. The purified, labeled DNA was further treated two or three times with RNase.

Immobilization of DNA on nitrocellulose filters. The DNA was diluted in standard saline citrate (SSC: $0.15 \mathrm{M} \mathrm{NaCl}$ plus $0.015 \mathrm{M}$ sodium citrate) and denatured by boiling for $6 \mathrm{~min}$ with quick cooling. The denatured DNA in SSC was slowly passed through a membrane filter (Millipore Corp., 100-nm pore size, VCWP2500). The filter was washed with distilled water before use. After application of DNA, the filter was dried overnight at room temperature and then in a vacuum oven at $80 \mathrm{C}$ for $2 \mathrm{~h}$. Approximately $30 \mu \mathrm{g}$ of DNA, calculated from optical density absorption at $260 \mathrm{~nm}$ of the DNA solution before and after filtration, were usually immobilized on each filter.

DNA-DNA hybridization. A filter on which unlabeled DNA was immobilized was incubated in a scintillation vial containing $1 \mathrm{ml}$ of preincubation mixture (PM) at $65 \mathrm{C}$ for $6 \mathrm{~h}$ according to Denhardt (7). The filter was then placed in another vial containing $1 \mathrm{ml}$ of $6 \times \mathrm{SSC}$, to which was added about $3 \mu \mathrm{g}$ of labeled and sheared DNA, and incubated at 67 to $68 \mathrm{C}$ for $12 \mathrm{~h}$. After the hybridization was completed, the filter was carefully washed with $30 \mathrm{ml}$ of $0.1 \times$ SSC on each side. It was then dried at room temperature, placed in a vial containing a toluene scintillation solution, and assayed for radioactivity in a liquid scintillation counter (Horiba, Kyoto). As it was impossible to immobilize the same amount of the unlabeled DNA on each filter, the labeled DNA was hybridized with the unlabeled DNA in unequal amounts. The labeled DNA hybridized with the unlabeled DNA, therefore, was determined by the count per $1 \mu \mathrm{g}$ of unlabeled DNA. The amount of DNA on the filter was estimated after each hybridization by using Burton's modification of the diphenylamine reaction (5). (The DNA on the filter was first hydrolyzed by heating the filter at $70 \mathrm{C}$ for $30 \mathrm{~min}$ in $0.5 \mathrm{~N}$ perchloric acid.)

\section{RESULTS}

Lack of thymidine kinase activity in $C$. renale. $C$. renale strains ATCC 10848 (type I), 46 (type II), and 43 (type III), and $E$. coli strains $\mathrm{H} / \mathrm{r} 30 \mathrm{RT}^{+}$and $\mathrm{H} / \mathrm{r} 30 \mathrm{RT}^{-}$, as controls, were cultivated at $37 \mathrm{C}$ for $72 \mathrm{~h}$ in 1 $\mathrm{ml}$ of the Casamino Acids medium containing 1 $\mu \mathrm{Ci}$ of ${ }^{3} \mathrm{H}$-thymidine per $\mathrm{ml}$. The cells were harvested by centrifugation. The radioactivity incorporated into the cells per milliliter of culture was 83 to 127 counts/min for the strains of $C$. renale, whereas it was 22,714 to 29,148 counts/min for the strains of $E$. coli. Thus ${ }^{3} \mathrm{H}$-thymidine was incorporated into the cells of $E$. coli but not into the cells of $C$. renale. This fact suggests that $C$. renale may not possess thymidine kinase activity. Thymidine kinase activity of $C$. renale was, therefore, measured by the method of Bresnick and Thompson (4). The results (Table 1) indicate that the thymidine kinase activity of $C$. renale is extremely low, whereas that of $E$. coli and of dog kidney cells infected with infectious canine hepatitis virus is high. The lack of thymidine kinase activity in cells of $C$. renale has thus been demonstrated.

Incorporation of ${ }^{3} \mathrm{H}$-uridine into the DNA of C. renale. A $10-\mu \mathrm{Ci}$ amount of ${ }^{3} \mathrm{H}$-uridine was added to $1 \mathrm{ml}$ of the Casamino Acids medium in which $C$. renale ATCC 10848 was then inoculated. The radioactivity incorporated into the cells of ATCC 10848 was 415,700 counts per min per cell. Incorporation of ${ }^{3} \mathrm{H}$-uridine into the DNA was then determined as follows. Purified DNA was obtained from the cells of ATCC 10848 grown in $400 \mathrm{ml}$ of broth containing ${ }^{3} \mathrm{H}$-uridine $(1 \mu \mathrm{Ci} / \mathrm{ml})$, using the purification procedure involving RNase treatment. The radioactivity of the purified DNA solution, which was RNase $(100 \mu \mathrm{g} / \mathrm{ml})$ resistant, was 1,693 counts per min per $25 \mu$ liters. The labeled DNA was, however, extremely sensitive to DNase; the radioactivity decreased to one-tenth after the treatment with DNase $(20 \mu \mathrm{g} / \mathrm{ml}$; for $1 \mathrm{~h}$ at $37 \mathrm{C})$. The results indicate that the DNA was labeled with tritium from ${ }^{3} \mathrm{H}$-uridine. The specific activity of the labeled DNA of ATCC 10848 (type I) was 1,963 counts per min per $\mu \mathrm{g}$, that of strain 46 (type II) was 1,022 counts per min per $\mu \mathrm{g}$, and that of strain 42 (type III) was 430 counts per min per $\mu \mathrm{g}$. In the following hybridization experiments, therefore, the DNA of $C$. renale labeled with ${ }^{3}$ H-uridine was used.

Determination of the ratio on the filter of labeled DNA to unlabeled DNA. The ability of

TABLE 1. Thymidine-kinase activities of $C$. renale and of other cells

\begin{tabular}{l|c|c}
\hline \multirow{2}{*}{ Cells } & \multicolumn{2}{|c}{ Thymidine kinase activity $^{a}$} \\
\cline { 2 - 3 } & $\begin{array}{c}\text { 0 min } \\
\text { (counts/ } \\
\text { min) }\end{array}$ & $\begin{array}{c}10 \mathrm{~min} \\
\text { (counts/ } \\
\text { min) }\end{array}$ \\
\hline $\begin{array}{l}\text { C. renale } \\
\text { ATCC 10848 (type I) }\end{array}$ & 211 & \\
$\begin{array}{l}\text { Strain 46 (type II) } \\
\text { E. coli } \\
\text { Infectious canine hepatitis } \\
\text { virus-infected dog kidney } \\
\text { cells }\end{array}$ & 237 & 303 \\
\hline
\end{tabular}

${ }^{a}$ Expressed as ${ }^{3} \mathrm{H}$-thymidine incorporated into thymidylate.

${ }^{b}$ Forty hours after infection. 
labeled DNA to hybridize with unlabeled DNA on filters was tested. When unlabeled DNA immobilized on the filter was fixed at $35 \mu \mathrm{g}$, the rate of hybridization increased in proportion as labeled DNA was increased to the amount of $4.1 \mu \mathrm{g}$. When labeled DNA added to unlabeled DNA was fixed at $4 \mu \mathrm{g}$, the rate of hybridization was increased in proportion as unlabeled DNA was increased to the amount of $44.5 \mu \mathrm{g}$. From this, it was determined that the rate of hybridization is highest when the ratio of labeled DNA to unlabeled DNA on the filter is $1: 10$.

DNA hybridization among the three types of C. renale. The labeled DNA from each strain of three types of $C$. renale was hybridized respectively with unlabeled DNA from six strains of $C$. renale. The DNA of $C$. pseudotuberculosis and $E$. coli $\mathrm{O}-111$ were used as controls. The results are given in Table 2 .

The hybridization between different types was always lower than that obtained in the homologous system. Type I (ATCC 10848) had a mean of $45 \%$ DNA binding with type II (strain 46) and a 55\% DNA binding with another strain (strain 45) of type II. Type I and type II were found to be, therefore, not so closely related. Type I had only a mean of $15 \%$ and a $20 \%$ DNA binding with type III strains 42 and 43 , respectively, indicating that type I and type III were unrelated. Type II (strain 46) had a mean of $66 \%$ DNA binding with type I (ATCC 10848) and a mean of $71 \%$ DNA binding with type III (strain 42). Hence, the indications were that type II might have common DNA, partly with type I and partly with type III. Type III (strain 42) had a mean DNA homology of $47 \%$ with type I ATCC 10848 and a mean $57 \%$ with type II strain 46 ; hence, a not too close relationship was indicated.

C. pseudotuberculosis was unrelated to $C$. renale, as was $E$. coli. It has been reported generally that the same species have approximately more than $80 \%$ DNA homology $(8,16$, 24). From this standpoint, types I, II, and III of $C$. renale might be of different species.

\section{DISCUSSION}

The DNA hybridization technique has been used to study genetic relationships among many bacterial groups and among yeasts, such as the Enterobacteriaceae (3, 20), Bacillus (23), Pseudomonas (6), Pasteurella (22), Streptococcus (24), Neisseria (16), Agrobacterium (12), Brucella (15), Candida (2), Mycoplasma (21), Leptospira (9), Mycobacterium (8), and Clostridium botulinum $(18,19)$.

TABLE 2.DNA homologies ${ }^{a}$ in the three types of C. renale

\begin{tabular}{l|c|c|c}
\hline \multirow{2}{*}{ Unlabeled DNA } & \multicolumn{3}{|c}{ Labeled DNA (\%) } \\
\cline { 2 - 3 } & $\begin{array}{c}\text { C. renale } \\
\text { type I } \\
\text { ATCC 10848 }\end{array}$ & $\begin{array}{c}\text { C. renale } \\
\text { type II } \\
\text { strain 46 }\end{array}$ & $\begin{array}{c}\text { C. renale } \\
\text { type III } \\
\text { strain 42 }\end{array}$ \\
\hline C. renale & & & 47 \\
Type I ATCC 10848 & $100^{b}$ & 66 & $(35,60)$ \\
Type I ATCC 19412 & 80 & $(61,63,72)$ & 57 \\
Type II strain 46 & $45^{d}$ & 100 & $(50,63)$ \\
Type II strain 45 & $(40,46,48)$ & 51 \\
Type III strain 42 & 55 & 79 & 100 \\
Type III strain 43 & 15 & 71 & - \\
C. pseudotuberculosis ATCC 809 & 20 & $(67,70,77)$ & 15 \\
\hline
\end{tabular}

\footnotetext{
${ }^{a}$ Expressed in terms of percentage binding for heterologous reactions relative to those of the homologous reactions.

$b^{b}$ The radioactivity (counts per minute) of each homologous reaction was 989 (type I), 1,315 (type II), and 306 (type III).

c Not done.

$d$ Average of the percentage of the repeated experiments shown in parentheses.
} 
In this paper, the DNA hybridization technique was applied to determine the relationships among members of $C$. renale. The results indicated that types I, II, and III were not so closely related. The results of the DNA homology test may suggest that types I, II, and III should be recognized as different species. However, the taxonomic relationship of the three types of $C$. renale will be determined after a numerical taxonomy study of this species, which is now in progress.

There was a lack of concurrence in the data on the cross-homology studies. For example, type I DNA only absorbed to a level of $15 \%$ to type III DNA, whereas type III DNA absorbed to type I DNA to a level of $47 \%$. This was the most striking example. Peterson and Pollock (21) reported that the lack of concurrence in the data in their cross-homology studies was due to difference of genome size of each DNA. This might also be the case in our study.

C. pseudotuberculosis was not closely related to the strains of $C$. renale from the view point of DNA homology. This is in accord with the results of the numerical taxonomy study of corynebacteria by Harrington (10).

It is interesting to note that thymidine was not incorporated into the DNA of $C$. renale due to the lack of thymidine kinase activity, but the DNA of C. renale was labeled with the tritium from ${ }^{3} \mathrm{H}$-uridine. The uridine tritiated in the $5^{\prime}$ position was originally used as the RNA precursor because the tritium in the $5^{\prime}$ position is lost under biological conditions when uridine is methylated to thymidine (11). In the present study, however, the tritium of ${ }^{3} \mathrm{H}$-uridine was incorporated into the bacterial DNA. Presumably, the labeled uridine was converted to deoxycytidine derivatives after phosphorylation and was incorporated into the DNA. Much higher specific activity might be obtained if labeled adenine were used instead of ${ }^{3} \mathrm{H}-$ uridine.

Tritium from ${ }^{3} \mathrm{H}$-uridine was incorporated in the DNA of type III strains in smaller amounts than that incorporated in types I and II. Thus, it may be surmised that type III may possibly be different from types I and II in the metabolic pathway of nucleic acid.

\section{ACKNOWLEDGMENTS}

We wish to express our deep gratitude to G. Yoshii and T. Kobayashi, Department of Experimental Radiobiology, Faculty of Veterinary Medicine, Hokkaido University, Sapporo, Japan, for valuable suggestions concerning the radioisotope work and to S.
Kubo, Department of Biochemistry of the same faculty, for helpful advice.

\section{REPRINT REQUESTS}

Address requests for reprints to: Dr. Ryo Yanagawa, Department of Hygiene and Microbiology, Faculty of Veterinary Medicine, Hokkaido University, Sapporo, Japan.

\section{LITERATURE, CITED}

1. Albach, R. A., M. J. Gerber, and E. R. Brown. 1970. In vitro uptake of tritium from uridine$5-\mathrm{H}^{3}$ into RNA (and DNA) in normal and murine leukemia virus infected mouse embryo tissue. Can. J. Microbiol. 16:1095-1099.

2. Bak, A. L., and A. Stenderup. 1969. Deoxyribonucleic acid homology in yeasts. Genetic relatedness within the genus Candida. J. Gen. Microbiol. 59:21-30.

3. Brenner, D. J., G. R. Fanning, K. E. Johnson, R. V. Citarella, and S. Falkow. 1969. Polynucleotide sequence relationship among members of Enterobacteriaceae. J. Bacteriol. 98:637-650.

4. Bresnick, B., and U. B. Thompson. 1965. Properties of deoxythymidine kinase partially purified from animal tumors. J. Biol. Chem. 240:39673974.

5. Burton, K. 1956. A study of the conditions and mechanism of the diphenylamine reaction for the colorimetric estimation of deoxyribonucleic acid. Biochem. J. 62:315-322.

6. De Ley, J., I. W. Park, R. Tijtgat, and J. V. Ermengen. 1966. DNA homology and taxonomy of Pseudomonas and Xanthomonas. J. Gen. Microbiol. 42:43-56.

7. Denhardt, D. T. 1966. A membrane-filter technique for the detection of complementary DNA. Biochem. Biophys. Res. Commun. 23:641-646.

8. Gross, W. M., and L. G. Wayne. 1970. Nucleic acid homology in the genus Mycobacterium. J. Bacteriol. 104:630-634.

9. Haapala, D. K., M. Rogul, L. B. Evans, and A. D. Alexander. 1969. Deoxyribonucleic acid base composition and homologies studies of Leptospira. J. Bacteriol. 98:421 428.

10. Harrington, B. J. 1966. A numerical taxonomical study of some corynebacteria and related organisms. J. Gen. Microbiol. 45:31-40.

11. Hayhoe, F. G. J., and D. Quaglino. 1965. Autoradiographic investigations of RNA and DNA metabolism of human leucocytes cultured with phytohaemagglutinin. Nature (London) 205:151154.

12. Heberlein, G. T., J. De Ley, and R. Tijtgat. 1967. Deoxyribonucleic acid homology and taxonomy of Agrobacterium, Rhizobium, and Chromobacterium. J. Bacteriol. 94:116-124.

13. Hirai, K., and R. Yanagawa. 1967. Nutritional requirements of Corynebacterium renale. Jap. J. Vet. Res. 15: 121-134.

14. Hiramune, T., S. Inui, N. Murase, and R. 
Yanagawa. 1971. Virulence of three types of Corynebacterium renale in cows. Amer. J. Vet. Res. 32:237-242.

15. Hoyer, B. H., and N. B. McCullough. 1968. Homologies of deoxyribonucleic acids from $\mathrm{Bru}$ cella ovis, canine abortion organisms, and other Brucella species. J. Bacteriol. 96:1783-1790.

16. Kingsbury, D. T. 1967. Deoxyribonucleic acid homologies among species of the genus Neisseria. J. Bacteriol. 94:870-874.

17. Kumazawa, N., and R. Yanagawa. 1969. DNA base compositions of the three types of Corynebacterium renale. Jap. J. Vet. Res. 17:115-120.

18. Lee, W. H., and H. Riemann. 1970. Correlation of toxic and non-toxic strains of Clostridium botulinum by DNA composition and homology. J. Gen. Microbiol. 60: 117-123.

19. Lee, W. H., and H. Riemann. 1970. The genetic relatedness of proteolytic Clostridium botulinum strains. J. Gen. Microbiol. 64:85-90.

20. McCarthy, B. J., and E. T. Bolton. 1963. An approach to the measurement of genetic relatedness among organisms. Proc. Nat. Acad. Sci. U.S.A. 50: 156-164.

21. Peterson, A. M., and M. E. Pollock. 1969. Deoxyribonucleic acid homology and relative genome size in Mycoplasma. J. Bacteriol. 99:639-
644.

22. Ritter, D. B., and R. K. Gerloff. 1966. Deoxyribonucleic acid hybridization among some species of the genus Pasteurella. J. Bacteriol. 92:1838-1839.

23. Takahashi, H., H. Saito, and Y. Ikeda. 1966. Genetic relatedness of spore bearing bacilli studied by the DNA agar method. J. Gen. Appl. Microbiol. 12:113-118.

24. Weissman, S. M., P. R. Reich, N. L. Somerson, and R. M. Cole. 1966. Genetic differentiation by nucleic acid homology. IV. Relationships among Lancefield groups and serotypes of streptococci. J. Bacteriol. 92:1372-1377.

25. Yanagawa, R., H. Basri, and K. Otsuki. 1967. Three types of Corynebacterium renale classified by precipitin reactions in gels. Jap. J. Vet. Res. 15:111-120.

26. Yanagawa, R., and K. Otsuki. 1970. Some properties of the pili of Corynebacterium renale. J. Bacteriol. 101:1063-1069.

27. Yanagawa, R., K. Otsuki, and T. Tokui. 1968. Electron microscopy of fine structure of Corynebacterium renale with special reference to pili. Jap. J. Vet. Res. 16:31-37.

28. Yanagawa, R., M. Shinagawa, and K. Nerome. 1968. Lysogeny in Corynebacterium renale. Jap. J. Vet. Res. 16:121-127. 